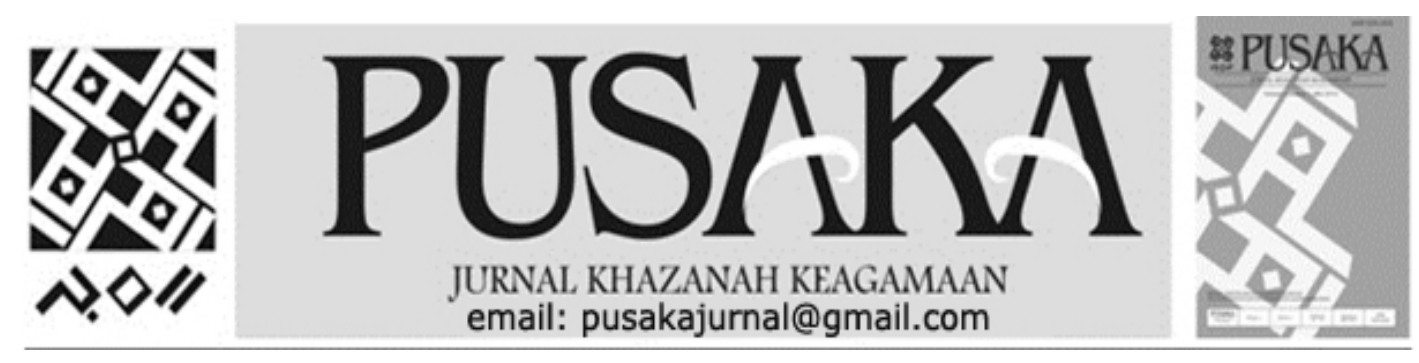

\title{
Bunga Mendowe: Cerita Rakyat Massenrempulu Dan Pengaruhnya Dalam Kehidupan
}

Bunga Mendowe: Massenrempulu Folklore and its Influence in Social Life

\author{
Mustafa \\ Balai Bahasa Sulawesi Selatan \\ Jalan Sultan Alauddin Km 7 Talasalapang, Makassar Telp. (0411) 882401 \\ Email: lamadaremmeng@gmail.com
}

\begin{tabular}{|c|c|}
\hline $\begin{array}{c}\text { Info } \\
\text { Artikel }\end{array}$ & Abstract \\
\hline $\begin{array}{c}\text { Diterima } \\
23 \\
\text { Januari } \\
2017 \\
\\
\text { Revisi I } \\
13 \\
\text { Maret } \\
2017\end{array}$ & $\begin{array}{l}\text { Bunga Mendowe salah satu karya sastra masyarakat Massenrempulu yang sarat } \\
\text { dengan nilai dan konsep-konsep kehidupan yang disampaikan secara lisan, turun } \\
\text { temurun dari generasi ke generasi kepada penuturnya. Artikel ini mendeskripsikan } \\
\text { salah jenis satu karya sastra legenda tentang kehidupan dalam masyarakat etnis } \\
\text { Enrekang. Legenda ini bercerita tentang kisah pernikahan yang tidak didasari oleh } \\
\text { cinta dan bagaimana akibat yang bisa timbul bila sering meninggalkan istri begitu } \\
\text { lama dirantau orang yang dibumbui dengan cerita supranatural sehingga cerita } \\
\text { tersebut menarik untuk dibaca dan dicerna. Di samping itu cerita tersebut dapat } \\
\text { menjadi bahan nasihat dan pembelajaran bagi anak cucu untuk bekal dihari } \\
\text { mendatang agar tidak salah langkah/tersesat. Teori yang digunakan adalah teori } \\
\text { berdasarkan Levi-Strauss yang dicontohkan Ahimsa dalam buku Strukturalisme } \\
\text { Levi-Strauss Mitos dan Karya Sastra pada cerita Pitoto' si Muhammad' } \\
\text { (2001:195-257) dengan metode analisis deskriptif. Hasil yang ditemukan } \\
\text { menunjukkan adanya hubungan yang terstruktur antarelemen dalam cerita dan } \\
\text { kondisi sosial di masyarakat. } \\
\text { Kata kunci: cerita rakyat; struktur cerita; relasi sosial }\end{array}$ \\
\hline $\begin{array}{c}\text { Revisi II } \\
5 \\
\text { April } \\
2017\end{array}$ & $\begin{array}{l}\text { Bunga Mendowe is one of the literary societyof Massenrempulu laden with values } \\
\text { and concepts of life were delivered orally, from generation to generation to the } \\
\text { speakers. This article describes one kind of literary legends about the life of the } \\
\text { ethnic Enrekangcommunities. This legend tells the story of the marriage that is not } \\
\text { based on love and how that can arise when the result is often left his wife so long } \\
\text { at other land people are peppered with stories of supernatural so that the story is } \\
\text { interesting to read and digest. In addition, the story can be advice and learning } \\
\text { subjects for our children for provisions on the day the order is not one step / lost. } \\
\text { The theory used is based on the theory of Levi-Strauss exemplified in the book } \\
\text { Ahimsa Structuralism Levi-Strauss Myth and Literary of the story Pitoto 'The } \\
\text { Mohammed' (2001: 195-257) with descriptive analysis method. Results found } \\
\text { indicate a structured relationship between elements in stories and social } \\
\text { conditions in the community. } \\
\text { Keywords: folklore; story structure; social relationships }\end{array}$ \\
\hline
\end{tabular}




\section{PENDAHULUAN}

Dalam upaya pelestarian, sastra lisan (khususnya sastra klasik) yang sarat dengan nilai-nilai moral, budaya, kearifan lokal, dan pola hubungan masyarakat yang bersangkutan di daerah di mana sastra lisan itu lahir dan berkembang. Oleh karena itu, sastra (daerah) harus ditumbuhkembangkan dalam menghadapi arus globalisasi yang memonopoli kehidupan generasi muda dewasa ini. Hal ini sejalan dengan pernyataan Damono (1994) yang mengatakan bahwa karya sastra dalam kaitannya dengan sastra daerah mencerminkan nilai budaya yang dianut atau yang diemban oleh pendukung bahasa daerah tersebut. Salah satu upaya tersebut adalah dengan pengembangan nilai-nilai budaya dan kearifan lokal yang terkandung dalam sastra daerah. Selain itu, upaya pengembangan pola hubungan antar masyarakat dapat terwujud melalui karya sastra. Hal ini menandakan bahwa dalam karya sastra tidak menutup kemungkinan terdapat pola hubungan antarmasyarakat melalui karya sastra masyarakat yang bersangkutan, misalnya melalui sastra lisan.

Sastra

lisan atau sastra

rakyat adalah karya sastra dalam bentuk ujaran (lisan), tetapi sastra itu sendiri berkutat di bidang tulisan. Sastra lisan membentuk komponen budaya yang lebih mendasar, tetapi memiliki sifat-sifat sastra pada umumnya. Masyarakat yang belum mengenal huruf tidak punya sastra tertulis, tetapi mungkin memiliki tradisi lisan yang kaya dan beragam, seperti epik, cerita rakyat, peribahasa, dan lagu rakyat yang secara efektif membentuk sastra lisan. Sekalipun semuanya disatukan dan dicetak oleh para ahli cerita rakyat dan paremiografer, hasilnya masih disebut "sastra lisan".

Masyarakat yang mengenal huruf kemungkinan masih melanjutkan tradisi lisan, biasanya di dalam keluarga (seperti pengantar tidur) atau struktur sosial informal. Sehubungan dengan hal itu, Enre (1981:1) dengan tegas mengatakan bahwa sastra daerah merupakan bagian suatu kebudayaan yang tumbuh dan berkembang di tengahtengah masyarakat yang pewarisannya melalui lisan dari generasi ke generasi. Sastra yang demikian tidak saja berfungsi sebagai media hiburan atau pengisi di waktu senggang, tetapi juga merupakan penggambaran sikap atau pandangan dan cita-cita kelompok masyarakat tertentu.

Memang, harus diakui bahwa sebagian orang menganggap karya sastra, khususnya cerita rakyat adalah sesuatu yang mengada-ada atau mengawan-awan dan tidak berpijak ke bumi, atau sesuatu yang dianggap karya para pelamun yang hanya menghabiskan waktu dan tidak membawa manfaat sama sekali di dalam kehidupan. Padahal, jika direnungkan secara mendalam sastra tidak seperti yang disangkakan orang. Dengan sentuhan bahasa yang indah, sastra menunjukkan perannya yang sangat mendasar dalam membangun manusia yang berkearifan demi terwujudnya nilainilai kemanusiaan. Kearifan itu akan mengkristal dalam diri setiap orang yang mengakrabinya dan akan menjelma sebagai sesuatu yang bernilai sekaligus akan mencirikan suatu kelompok sebagai pembeda 
dari kelompok yang lain. Sastra sebagai bagian yang tak terpisahkan dari kehidupan manusia sesungguhnya dapat menjadi penerang bagi umat manusia (Suyitno, 1986).

Sastra lisan daerah Enrekang sebagai bagian dari kebudayaan secara umum tumbuh dan berkembang seiring dengan perkembangan serta kemajuan masyarakat. Salah satu perannya yang sangat menonjol dalam kehidupan bermasyarakat adalah sebagai pelestari dan pengokoh nilainilai kultural. Nilai-nilai kultural seperti keagamaan, kejujuran (lambuq), etos kerja (tinuluq), kehormatan diri (paqpalabinna), keberanian (katarukan), tetap pada pendirian (toqdopuli) merupakan butir-butir penting yang sejak dahulu menghiasi pola tingkah laku nenek moyang manusia Enrekang. Nilainilai seperti itu terekam dalam karya sastra yang mereka miliki, termasuk cerita rakyat. Makna-makna yang muncul dalam butiran-butiran nilai hanya dapat terungkap jika seorang (peneliti) memahami segala hal yang terkait dengan pemilik sastra tersebut termasuk latar sosial budayanya (Pradopo, 2007: 113). Tanpa itu semua tidak mungkin diperoleh kandungan maknanya.

Etnis Enrekang sangat kaya dengan cerita rakyat. Sikki dkk (1986) pernah mengumpulkan beberapa cerita rakyat (30 cerita rakyat) dalam beberapa wilayah dialek yang berbeda di kabupaten Enrekang. Hal ini dapat dipastikan bahwa yang belum terinventarisasi jauh lebih banyak daripada yang telah disebutkan.
Masalah mendasar yang muncul dalam artikel ini adalah adanya anggapan bahwa menikah tanpa cinta dan kasih sayang bisa bahagia, langgeng, dan rukun bahagia dikalangan masyarakat khususnya masyarakat Enrekang. Apakah anggapan masyarakat ini mempunyai relasi dengan muatan cerita? Inilah yang menjadi masalah pokok dalam artikel ini.

Artikel ini diharapkan dapat memberi kontribusi dalam meningkatkan apresiasi dan pemahaman kepada masyarakat betapa pentingnya karya sastra tersebut sebagai salah satu bahan pembelajaran dalam melakoni hidup ini. Selain itu, artikel ini diharapkan pula membawa informasi baru, terutama dikalangan para peneliti sastra daerah untuk melengkapi informasi yang sudah ada. Oleh karena itu, artikel ini sangat diharapkan sampai ke tangan masyarakat dalam bentuk terbitan.

\section{Kerangka Teori}

Penelitian ini menggunakan pendekatan struktural berdasarkan prinsip antarhubungan Data yang digunakan dalam analisis adalah data dari cerita BungaMendowe, yaitu salah satu karya sastra dari daerah Enrekang di Sulawesi Selatan, dan teori yang digunakan adalah teori strukturalisme menurut LeviStrausss,yaitu dengan menjelaskan sastra lisan (cerita rakyat) itu menunjuk fungsinya, yakni sebagai media untuk mengembangkan suatu argumen logis dalam bentuk preposisi-preposisi.

Dalam analisis struktural ini dibedakan menjadi dua macam: struktur lahir, struktur luar (surface 
structure) dan struktur batin, struktur dalam (deep structure). Struktur luar adalah relasi-relasi antarunsur yang dapat kita buat atau bangun berdasar atas ciri-ciri luar atau ciri-ciri empiris dari relasi-relasi tersebut. Sedang struktur dalam adalah susunan tertentu yang dibangun berdasarkan atas struktur lahir yang telah berhasil dibuat. Namun, tidak selalu tampak pada sisi empiris dari fenomena yang kita pelajari. Struktur dalam inilah yang lebih tepat disebut model untuk memahami fenomena yang diteliti, karena melalui struktur inilah peneliti kemudian memahami berbagai fenomena budaya yang dipelajari (Ahimsa, 2013: 61)

Ceriteme adalah katakata,frasa, kalimat, dan bagian dari alinea atau alinea yang dapat ditempatkan dalam relasi tertentu dengan ceriteme yang lain sehinggamenampakkan maknamakna tertentu. Ceriteme ini bisa mendeskripsikan suatu pengalaman, sifat-sifat, latar belakang kehidupan, interaksi atau hubungan sosial ataupun hal-hal lain dari tokoh-tokoh dalam cerita yang penting artinya bagi analisis tersebut. Tentu saja derajat kepentingan setiap ceriteme ini juga tersebar diberbagai tempat dalam konteks cerita (Ahimsa dalam Jamaluddin, 2013: 22).

Langkah-langkah analisis

1. Membaca keseluruhan cerita terlebih dahulu guna memperoleh pengetahuan dan kesan tentang isi cerita, tokohtokohnya, dan berbagai peristiwa yang dialami mereka.

2. Membagi cerita dalam beberapa ceriteme-ceriteme.Sebuah ceriteme hanya dapat diketahui maknanya atau pengertiaannya setelah ditempatkan dalam hubungan ceriteme lain.

3. Tindakan atau peristiwa ini yang merupakan miteme hanya dapat ditemukan pada tingkat kalimat. penemuan miteme dilakukan dengan memperhatikan kalimat yang memperlihatkan suatu pengertian tertentu. Selanjutnya, miteme disusun secara diakronis dan sinkronis, atau mengikuti sumbu sintagmatis dan paradigmatisnya dengan elemen lain. Cara ini akan menggambarkan relasi yang sama dan tidak sama.

5. Memberikan interpretasi berdasarkan keseluruhan relasi dalam cerita yang berhasil diperoleh, serta makna referensial maupun kontekstual dari elemen-elemen yang ada dalam cerita tersebut.

Pengkajian ini menggunakan metode deskripsi, yaitu dengan memaparkan semua peristiwa, baik waktu, tempat, tokoh, dan latar sosial yang mencipta (Zaidan, dkk. 1994: 29). Di samping itu, dilakukan pula studi pustaka untuk memperoleh bahan kepustakaan yang dapat dijadikan acuan dalam membahas objek pengkajian (Vredebregt, 1985: 19; Kartodirdjo, 1989: 58).

Sementara itu, untuk membedah motif dan tipe cerita digunakan dua kriteria dasar tentang penggolongan sastra lisan. Penggolongan ini dikembangkan oleh Aarne-Thompson, yaitu tentang tipe dan motif. Kedua kriteria dasar tersebut; Pertama tentang pengklasifikasian dongeng ke dalam tujuh jenis tipe, yaitu (1) animal tales (dongeng tentang binatang), (2) tales of magic (dongeng tentang hal-hal 
yang magis), meliputi: tantangan supranatural, istri atau suami atau kerabat supranatural, tugas-tugas supranatural, dan dongeng-dongeng lainnya tentang supranatural., (3) religious tales (dongeng tentang keagamaan), (4) realistic tales atau novelle (dongeng tentang realistik), (5) Stupid orge/giant/devil tales (donegng tentang raksasa yang bodoh), (6) anecdotes and jokes tales (dongeng tentang anekdot dan lelucon), dan (7) formula tales (dongeng yang memiliki formula) (Taum, 2011: 85). Kedua, pengklasifikasiandongeng ke dalam beberapa jenis motif, yaitu (1) motif berupa benda, misalnya: tongkat wasiat, sapu ajaib, lampu ajaib, bunga mawar, tanah liat, bendabenda angkasa. Cerita asal usul manusia, dan lain-lain. (2) motif berupa hewan yang luar biasa, misalnya kuda yang bisa terbang, buaya siluman, singa berkepala manusia, raksasa, hewan yang bisa berbicara. (3) motif yang berupa suatu konsep, misalnya larangan atau tabu. Misalnya mengapa wanita hamil tak boleh makan pisang kembar. Mengapa seorang anak gadis tidak boleh makan di ambang pintu, dan lai lain. (4) motif suatu perbuatan (uji ketangkasan, minum alkohol, bertemu di gunung, turun dari gunung, menyamar sebagai fakir miskin, menghambakan diri, melakukan tindakan laku, tapa, melewati alam gaib, bertarung dengan raksasa, dll) (5) motif tentang penipuan suatu tokoh (raksasa, hewan), seperti cerita tentang kancil, raksasa yang bisa menelan manusia yang muda ditipu, dan lain-lain, dan (6) motif yang menggabarkan tipe orang tertentu, misalnya yang sangat pandai, seperti Abunawas, tokoh yang selalu tertimpa nasib sial seperti si Pandir, dan si Kabayan, tokoh yang sangat bijaksana seperti raja Sulaeman, tokoh pemberani seperti si Pitung, tokoh pelaut yang pemberani seperti Hang Tuah, dan lain-lain.

\section{Metode dan Teknik}

Penelitian ini ini menggunakan metode deskriptif kualitatif sehingga dpat diperoleh gambaran yang jelas tentang cerita yang menjadi objek penelitian. Sumber data penelitian ini adalah cerita rakyat yang berjudul Bunga Mendowe, yaitu sebuah cerita rakyat yang berasal dari daerah Enrekang.

Sementara itu, teknik yang digunakan dalam penelitian ini adalah membaca secara intensif cerita tersebut untuk menemukan atau menandai bagian-bagian penting yang membangun analisis. Teknik yang digunakan menglah data adalah teknik pencatatan dan studi pustaka.

\section{PEMBAHASAN \\ Isi Cerita}

Bunga Mendoe adalah seorang putri raja dari Uluwai Kabupaten Tana Toraja yang melarikan diri dari keluarga dan meninggalkan kampung halamannya ketika hendak dinikahkan dengan seorang pemuda yang tidak dikenalnya. Dalam pelariannya, ia tiba di sebuah kerajaan yang bernama Pangbarani. Di daerah itu, dia diijinkan tinggal oleh keluarga raja. Pada saat itu, seorang putra raja yang bernama Cinangki Wale tertarik pada kecantikan Bunga Mendowe. Namun, Bunga Mendowe tidak mencintai pemuda tersebut. Sang 
Pemuda sangat menaru hati pada Bunga Mendowe karena cintanya itu ia mengancam akan membuat kekacauan apabila tidak dinikahkan dengan Bunga Mendowe. Akhirnya, dengan sangat terpaksa Bunga Mendowe harusmenerima lamaran pemuda itu. Alasan lainnya, karena Bunga Mendowe merasa berutang budi pada sang Raja (ayah Cinangki Wale) yang telah memberi izin untuk tinggal di daerah itu.

Pernikahan Cinangki Wale dan Bunga Mendowe pun dilaksanakan dan berlangsung amat meriah. Namun, dalam perjalanan hidup kedua pasangan itu tidak memberi kebahagiaan bagi Bunga Mendowe. Bunga Mendowesering ditinggal beberapa hari bahkan berbulan-bulan oleh suaminya yang berkunjung ke negeri tetangga untuk berdagang, memenuhi kegemaran berjudi dan sabung ayam. Bahkan biasa berharihari baru sang Suami pulang. Akibat sering ditinggal, Bunga Mendowe menjadi merasa kesepian.

Suatu waktu,Bunga Mendowe melihat seorang pemuda dan membuatnya jatuh hati kepada pemuda itu. Pemuda itu bernama Janggu Rara. Bunga Mendowe pun berusaha mencari cara untuk dapat berkenalan dengannya sampai pada suatu hari usahanya itu berhasil. Pucuk dicinta ulang tiba. Janggu Rara ternyata ada hati juga kepadanya. Terjalinlah hubungan dangan sangat akrab. Hubungan antara Bunga Mendowe dan Janggu Rara tercium oleh suaminya, Cinangki Wale. Betapa marahnya Cinangki Wale setelah mengetahui kejadian itu. Cinangki Wale amat murka lalu menjatuhkan hukum kepada Janggu Rara, yaitu dengan cara yang amat sadis dan biadab. Janggu Raa dibakar ke dalam api yang sedang berkobar. Melihat kejadian itu, Bunga Mendowe merasa kasihan dan tidak tega melihat kekasihnya diperlakukan seperti itu, Bunga Mendowelalu melompat masuk ke dalam kobaran api untuk menyertai kematian kekasihnya. Akhirnya, keduanya pun mati bersama dalam kobaran api yang menyala-nyala hingga tubuhnya menjadi abu.

Berkat kuasa Tuhan, dandoa kedua orang tua mereka, kedua abu jenazah itu kemudian menjelma menjadi mausia yang lebih tampan dan cantik dari sebelumnya. Keduanya kemudian hidup,lalu menikah, dan hidup berbahagia. Masyarakat Pangbarani pun bersepakat agar keduanya diangkat menjadi pemimpin daerah itu. Di bawah kekuasaan mereka berdua, negeri itu menjadi makmur, dan sejahtera.

Pada suatu hari, Bunga Mendowe balik ke kampung halamannya di Uluwai dengan maksud untuk mengunjungi kedua orang tuanya. Sesampainya di negeri itu, bukan kebahagiaan yang diperolehnya melainkan kesedihan ternyata ayahnya sudah meninggal dunia. Menurut berita yang ia dengar bahwa kematian ayahnya itu akibat kesedihannya yang berlarut-larut karena Bunga Mendowe pergi entah kemana meninggalkan istana yang tak diketahui arah tujuannya.

Bunga Mendowe pun merasa sangat terpukul dan bersalah akan kejadian itu, akibatnya ia pun jatuh sakit dan berselang beberapa lama ia meninggal dunia. Suaminya kemudian meminta agar jasad mayat 
Bunga Mendoe dibawa ke Pangbarani untuk dimakamkan di sana. Sepeninggal Bunga Mendowe, Janggu Rara juga merasa sangat sedih yang amat mendalam karena ditinggal oleh istri yang amat dicintainya. Karena duka yang berlarut-larut, Janggu Rara pun jatuh sakit dan meninggal dunia menyusul istrinya di alam baka.

Terjadi suatu keanehan, setelah kematian keduanya. Ulat-ulat yang keluar dari dalam kuburan mereka saling mengunjungi padahal tempatnya amat jauh. Melihat kejadian itu, pejabat istana pun berinisiatif untuk menyatukan kedua jasadnya dalam sebuah gua. Semenjak itu, ulat-ulat pun sudah tak tampak seperti yang biasa terlihat.

\section{Pengepisodean Cerita}

Simbol

$$
\begin{array}{ll}
\mathrm{BM} & \text { : Bunga Mendoe } \\
\mathrm{JR} & \text { : Janggu Rara } \\
\mathrm{CW} & \text { : Cinangki Wale }
\end{array}
$$

Episode 1: (Bunga Mendoe
hendak dinikahkan dengan orang
yang tidak dikenal dan realitas
kawin paksa di kalangan
masyarakat).
Episode ini (alinea1-4)
menggambarkan tentang Bunga
Mendoe (BM) yang berparas cantik
tiada bandingannya, karena
kecantikannya itu banyak pemuda
yang ingin mempersuntingnya,
termasuk putra raja dari negeri
seberang. Ayahanda putri BM
menerima pinangan itu dengan
persetujuan para hulubalang dan
penasehat istana, tapi BM sebagai
orang yang hendak dinikahkan tidak
dimintai pendapatnya.
Ketidaksetujuan BM ditunjukkan

tidak dengan melakukan perlawanan terbuka kepada ayahnya, melainkan dia berusaha melawan tekanan perasaan yang dirasakannya seorang diri. Hal itu kemudian menyebabkan dia jatuh sakit dan pada akhirnya memutuskan untuk meninggalkan istana demi menghindari perjodohan itu.

Tafsir Episode 1. Superiotas seorang ayah ditunjukkan dalam episode ini, dalam masyarakat Toraja dan Sulawesi Selatan pada umumnya. Ayah dianggap sebagai pemegang kekuasaan tertinggi dalam rumah tangga, mereka berhak memutuskan hal-hal yang dia anggap baik bagi keluarganya. Terkadang hal itu membuat keinginan ibu dan anak-anak dalam keluarga menjadi terabaikan, seperti yang terjadi pada BM. BM yang tidak berani menolak keinginan sang Ayah kemudian jatuh sakit.Hal ini, akibat adanya tekanan psikologis yang berat yang disebut psikomatis. Gangguan psikosomatis adalah penyakit yang melibatkan pikiran dan tubuh, di mana pikiran memengaruhi tubuh hingga penyakit muncul atau diperparah. Dengan kata lain, istilah gangguan psikosomatis digunakan untuk menyatakan penyakit fisik yang diduga disebabkan atau diperparah oleh faktor mental, seperti stres dan rasa cemas.

Penyakit BM tidak diketahui apa penyebabnya oleh penghuni istana dan warga Uluwai, hingga akhirnya, diputuskan untuk memanggil dukun yang dianggap dapat mengobati jenis penyakit yang seperti itu. Masyarakat Uluwai percaya bahwa ada jenis-jenis penyakit yang tidak dapat disembuhkan oleh tabib karena 
kadang kala penyakit tersebut dianggap berasal dari roh jahat yang sengaja dikirim kepada seseorang. Hal inilah yang menyebabkan dukun memiliki posisi tertentu di dalam masyarakat.

Dalam hubungannya dengan sistem kepercayaan masyarakat, dukun dijadikan tumpuan dan tempat menanyakan berbagai masalah kesehatan, dan keselamatan serta penghidupan seseorang yang datang kepadanya. Dukun, sebagai penyembuh penyakit bagi masyarakat tradisional mampu memberikan penjelasan, tafsiran bahkan memberikan "resep obat" berupa ramuan dari daun-daunan atau tanam-tanaman dan yang terbanyak dengan jampi-jampi melalui bacaan mantra yang ditulis oleh orang-orang terdahulu. Proses ini telah menjadi bagian dari kultur masyarakat. Dari beberapa studi mengenai dukun, tabib, pawang atau sanro di beberapa daerah di Indonesia, diperoleh kesimpulan bahwa mereka itu berfungsi untuk menangani berbagai penyakit jasmani dan rohani yang dialami oleh seseorang atau masyarakat luas.

Keyakinan akan kesaktian seorang dukun semakin diperjelas dengan kesembuhan penyakit yang dialami oleh BM. Mereka pun melaksanakan syukuran atas kesembuhan tersebut dengan mengadakan pesta sebagai wujud kebahagiaan atas nikmat yng mereka perolehnya. Hal ini juga merupakan salah satu budaya masyarakat yang masih dapat dijumpai hingga saat ini, masyarakat kita terbiasa mengadakan acara syukuran atas pencapaian suatu nikmay yang diberikan oleh Tuhan yang mereka peroleh. Hal tersebut biasanya ditandai dengan melakukan pemotongan hewan dan melaksanakan pesta yang diisi dengan beraneka macam makanan.

Tradisi seperti ini masih banyak dijumpai pada masyarakat Enrekang hingga saat ini meski mereka sudah menganuk agama Islam, seperti sebagian orang-orang yang akan menunaikan ibadah haji. Mereka sebelum berangkat, terlebih dahulu mengadakan acara kenduri syukuran lalu mengundang seluruh kerabat dekat dan jauh, dan tetangga serta seluruh kenalan meskipun jauh tempatnya. Ada beberapa jenis syukuran yang sering dijumpai, misalnya syukuran pasca panen, syukuran bersih desa, syukuran pesta laut. Konon katanya sebagai ungkapan rasa syukur kepada penguasa bumi, dan penguasa laut yang telahmemberikan rezeki berupa hasil bumi dan hasil laut yang melimpah lalu dengan memberikan sesajen. Hal itu dilakukan agar para penguasa alam berupa dewa-dewa dan jin-jin tidak marah.

Kesembuhan BM ditandai dengan pelaksanaan syukuran di istana Uluwai membuat BM merasa gundah karena terkenang akan rencana perjodohan yang hendak dilakukan oleh ayahandanya. BM lalu mencari jalan agar dapat terbebas dari perjodohan itu. BM kemudian memutuskan untuk lari dari istana meninggalkan keluarganya. Hal ini merupakan salah satu dampak dari perjodohan secara paksa. Pilihan untuk meninggalkan rumah dianggap sebagai jalan keluar yang paling jitu bagi seorang anak yang mengalami perjodohan paksa, Ia melakukan hal itu karena tidak cinta dengan pemuda 
yang dijodohkan kepadanya. Inilah yang dilakukan oleh dilakukan oleh BM dalam menghadapi masalahnya.

BM yang lari meningglkan istana kemudian sampai ke Pangbarani sebuah desa di daerah Baraka Kab. Enrekang. Di tempat itu, dia diterima dengan baik karena keramahan dan kebaikannya. Masyarakat setempat yang merasa senang dengan kehadiran BM kemudian mengantarkannya ke istana Pangbarani, di tempat itulah kemudian dia tinggal dan menetap. Sikap BM yang ramah dan baik hati merupakan pencerminan sikap mulia yang membuat dia dengan mudah diterima dikalangan masyarakat baru yang di datanginya. Hal itu memberikan gambaran kepada kita bahwa kalau mau diterima di suatu lingkungan dengan baik sikap dan yang baik perilaku perlu ditunjukkan dan menghormatai aturan yang berlaku di daerah tersebut.

Episode pertama dalam legenda Bunga Mendoe ini menggambarkan tentang perjodohan paksa yang memberikan dampak besar dalam kehidupan keluarga istana Uluwai.

\section{Episode 2: Bunga Mendowe dan Cinangki Wale (alinea 5-6).}

BM yang diperkenankan tinggal di istana Pangbarani menarik perhatian seorang putra raja yang bernama CW. Namun, BM tidak menaruh hati pada $\mathrm{CW}$, ia hanya menghormatinya sebagai putra raja, lain tidak. CW yang sudah terlanjur jatuh hati pada BM tidak dapat lagi melihat kenyataan bahwa BM tidak mencintainya, dia terus memaksakan keinginannya untuk menikahi BM, bahkan dia mengancam akan membakar istana apabila keinginannya itu tidak dipenuhi. Akhirnya, dengan sangat BM terpaksa menerima lamaran itu dan mereka pun menikah dalam sebuah pesta yang sangat meriah.

Tafsir Episode 2. Meskipun BM tidak memiliki perasaan cinta terhadap $\mathrm{CW}$ dia tidak kuasa menolak lamarannya, dikarenakan $\mathrm{CW}$ dianggap $\mathrm{BM}$ sebagai orang yang berjasa dalam kehidupankeluarganya yang tampa pamrih mau memberikan tumpangan hidup untuknya. Masyarakat Sulawesi Selatan pada umunya tidak mengenal kosa kata terima kasih dalam bahasa daerahnya. Hal ini menunjukkan mereka tidak terbiasa mengungkapkan rasa terima kasih melalui lisannya melainkan dalam bentuk laku dan perbuatan secara langsung. Hal inilah yang dilakukan oleh BM. BM beranggapan kebaikan seseorang merupakan hal yang harus dihargai dan dijunjung tinggi, mereka sedapat mungkin akan membalas kebaikan tersebut dengan kebaikan juga dengan berbagai cara. Apabila mereka tidak dapat membalasnya dengan harta yang mereka miliki, maka mereka akan mencoba dengan cara yang lain. Salah satu hal yang dapat dilakukan seperti apa yang dialami BM dalam cerita ini, yaitu dengan menerima lamaran seseorang yang sudah membantunya. Inilah yang menjadi dasar bagi BM dalam menerima lamaran CW meski pun tidak dicintainya. Tradisi ini masih berlangsung hingga saat ini, sehingga banyak perempuan atau laki-laki yang menikah bukan karena cinta tetapi dengan alasan ingin balas budi. 
Sementara itu, pernikahan dalam budaya setempat dianggap sebagai ajang bagi seorang untuk menunjukkan posisinya dalam masyarakat, sehingga semakin terhormat dan terpandang posisinya di masyarakat,maka akan semakin meriah pesta pernikahan yang akan dilansungkan. Hal ini juga yang ingin ditunjukkan keluarga CW sebagai keluarga bangsawan ditempat itu. Mereka menyelenggarakan pesta yang sangat meriah dan menghadirkan undangan dari berbagi daerah. Hal tersebut membuktikan bahwa mereka adalah keluarga yang terpandang dan mempunyai kedudukan sosial yang tinggi di masyarakat.

Episode kedua dalam legenda Bunga Mendowe menggambarkan tentang perjodohan paksa yang kembali dialami oleh BM.Namun, pada episode ini BM tidak punya pilihan lain selain menerima perjodohan tersebut.

\section{Episode 3:Kehidupan pernikahan Bunga Mendowe dan Cinangki Wale (alinea 7-13). \\ Pada episode ini digambarkan} kehidupan pernikahan $\mathrm{BM}$ dan $\mathrm{CW}$ yang tidak bahagia dikarenakan adanya salah satu pihak yang menikah karena keterpaksaan. CW yang sering meninggalkan istrinya untuk pergi berjudi sabung ayam, menyebabkan BM merasa kesepian dan akhirnya terpikat pada lelaki lain yaitu JR. pencarian BM akan sosok laki-laki yang dicintainya sebenarnya berawal dari perasaannya yang hampa kepada $\mathrm{CW}$, karena dia tidak bisa menerima cinta dari laki-laki yang telah menikahinya itu. Persoalan ini kemudian menjadi duri dalam daging bagi rumah tangga mereka yang akhirnya mencapai klimaksnya saat BM mulai berkenalan dengan laki-laki lain dan merasakan perasaan cinta yang tak pernah dirasakannya selama ini pada suaminya.

Tafsir Episode 3: Pernikahan tanpa didasari cinta akan menimbulkan berbagai dampak dimasa yang akan datang, antara lain kehidupan rumah tangga tidak harmonis.Terlihat kehidupan rumah tangga $\mathrm{BM}$ dengan $\mathrm{CW}$ yang menikah tanpa saling mencintai berjalan hambar, kurang harmonis, bahkan setiap hari hampir diwarnai pertengkaran, akibatnya kenyamanan hanya dapat diperoleh di luar rumah dan hal ini rentan untuk menggoyahkan kehidupan rumah tangga. Hal lain yang dapat timbul, yaitu banyaknya godaan yang dirasakarena kehidupan rumah tangga yang hambar dan sangat besar kemungkinan godaan datang dari luar.Dengan cinta, pasangan suamiistri akan menjadi lebih dekat, lebih mesra, dan dapat menciptakan suasana harmonis dalam rumah tangga. Dengan mencintai pasangan seseorang dapat mempertahankan hubungan dari gangguan luar yang dapat menerpa rumah tangga.

Kehidupan rumah tangga tanpa cinta yang dijalani BM bersama $\mathrm{CW}$, ditambah lagi kegemaran $\mathrm{CW}$ yang amat doyang bermain judi "sabung ayam" sehingga harus meninggalkan istrinya untuk waktu lama yang semakin memicu ketidakharmonisan dalam rumah tangga mereka, sampai akhirnya BM bertemu seorang pemuda tampan yang membuatnya jatuh cinta. Dengan berbagai cara, BM mencari jalan agar dapat 
perkenalan dengan pemuda itu dan berhasil. Dari sinilah awal perselingkuhan BM dan JR bermula.

Munculnya perselingkuhan dalam suatu keluarga dikarenakan luapan kekecewaan terhadap tidak terpenuhinya harapan. Tingginya harapan akan kebahagiaan justru menjatuhkan seseorang ke dalam jurang kekecewaan, sehingga ketika harapan tidak tampak maka masingmasing mulai mencari pasangan baru yang dirasa lebih cocok.

Selingkuh adalah segala bentuk perilaku yangsuka menyembunyikan sesuatu untuk kepentingan sendiri; tidak bertrerus terang; tidakjujur; curang; dan serong mengarah pada hubungan dengan melibatkan orang lain diluar pasangan sahnya dalam pernikahan (suami/istri).Dengan memberi atau menerima perlakuan yang seharusnya diberikan pada pasangan yang sah yaitu membentuk perlakuan dengan hubungan seksual antara dua orang.

Faktor penyebab terjadinya perselingkuhan antara lain adanya faktor internalberupa:

1. Konflik dalam pernikahan yang tidak kunjung selesai dan terusmenerus oleh perbedaan latar belakang pendidikan, perkembangan kepribadian, subkultur, serta pola hidup, yang menyebabkan ketidakserasian relasi antarpasangan.

2. Kekecewaan oleh berbagai macam sebab-musabab, seperti sifat yang berbeda, cara berkomunikasi yang kurang terasa pas, dan sebagainya.

3. Ketidakpuasan dalam kehidupan seksual oleh disfungsi seksual atau penyimpangan perilaku seksual lainnya.
4. Problema finansial.

5. Persaingan antarpasangan baik dalam karier dan perolehan penghasilan.

6. Perasaan kesepian karena pasangan yang terlalu sibuk dengan pekerjaan sehingga tidak memiliki waktu yang cukup untuk pasangannya.

Faktor lain yaitu faktor eksternal berupa:

1. Lingkungan pergaulan yang mendorong seseorang untuk mengambil keputusan mencoba menjalin hubungan perselingkuhan.

2. Kedekatan dengan teman lain jenis ditempat kerja yang berawal dari saling mencurahkan kesusahan dan kekecewaan dalam rumah tangga. Dari hal ini kemudian, terjalin kedekatan emosional yang berlanjut dengan kontak fisik intim.

Godaan erotis-seksual dari berbagai pihak, rekan kerja dan teman dengan motif tertentu.

Perselingkuhan yang dilakukan olen BM akhirnya diketahui oleh $\mathrm{CW}$ dan memyebabkannya sangat marah lalu menjatuhkan hukuman kepada JR dengan cara membakarnya hidup-hidup. BM yang merasa kasihan dan tidak setuju perlakuan itu pada kekasihnya lalu ikut melompat ke dalam api yang berkobar saat JR dibakar, mereka pun kemudian dibakar bersama-sama dan tubuhnya menjadi debu.

Episode IV:Kehidupan Pernikahan BM dan JR (alinea 14-19) dalam episode ini diceritakan tentang usaha orang tua BM dan JR untuk menghidupkan kembali anak mereka yang akhirnya berhasil. Setelah 
keduanya hidup, BM dan JR menjalani hidup baru dan kehidupan rumah tangga yang bahagia. Hal ini disebabkan keduanya saling mencintai sehingga kehidupan rumah tangga mereka berjalan harmonis. Pernikahan BM dan JR dilandasi dengan perasaan cinta. BM telah membuktikan keberanian JR menerima hukuman dari $\mathrm{CW}$ dan sebaliknya JR telah membuktikan kesetiaan BM yang rela ikut serta terjun ke dalam kobaran api yang membara dan membakarnya hiduphidup karena tidak tega melihat pujaan hatinya harus menjalani hukumannya sendiri.

Tafsir episode IV: Pernikahan yang bahagia diyakini dapat menyebabkan suami istri hidup lebih sehat dan perjalanan karir yang lebih cemerlang. Hal ini sejalan dengan yang dialami oleh BM dan JR. JR berhasil mencapai puncak karir dengan dinobatkan sebagai pemimipn di Pangbarani setelah menikah dengan BM, prestasi lain yang juga ditunjukkannya yaitu kehidupan rakyatnya yang sejahtera di bawah kepemimpinan mereka.

Namun, kebahagiaan tidaklah mungkin berlangsung abadi, cobaan akan selalu hadir dalam setiap kehidupan rumah tangga. Hal ini di alami oleh JR ketika BM meninggal dunia mendahuluinya. Perasaan sedih dan kehilangan sangat dirasakannya ketika belahan jiwanya meninggalkannya untuk selamanya. Kesedihan JR akibat kematian BM membuatnya mengalami depresi. Depresi merupakan gangguan suasana hati yang menyebabkan penderitanya terus-menerus merasa sedih. Berbeda dengan kesedihan biasa yang umumnya berlangsung selama beberapa hari, perasaan sedih pada depresi biasa berlangsung hingga berminggu-minggu atau berbulan-bulan. Selain memengaruhi perasaan atau emosi, depresi juga dapat menyebabkan masalah fisik, mengubah cara berpikir serta mengubah cara berperilakusi Penderita. Tidak jarang penderita depresi sulit menjalani aktivitas sehari-hari secara normal. Akibat dari depresi yang dialaminya, JR kemudian jatuh sakit dan akhirnya juga meninggal dunia. Perasaan cinta yang sangat kuat antara keduanya, terbawa sampai ke alam kematian. Ulat dari kubur mereka berdua saling mengunjungi padahal mereka dikubur di tempat yang berbeda. Hal ini membuktikan besarnya rasa cinta yang mereka miliki.

\section{Tipe}

Berdasarkan penggambaran cerita di atas, legenda Bunga Mendowe dapat dikategorikan ke dalam tales of magic (dongeng tentang hal-hal magis). Hal tersebut dapat dilihat pada deskripsi Bunga Mendowe dan Janggu Rara yang sudah meninggal dan menjadi abu. Namun dapat hidup kembali dengan rupa yang lebih cantik. Demikian pula Janggu Rarahidup juga dengan rupa lebih tampan dari sebelumnya. Sebaliknya, abu Cinangki Wale berubah menjadi beraneka jenis burung. Hal ini dikarenakan adanya kekuatan supranatural yang memungkin adanya kejadian tersebut.

Deskripsi lain tentang adanya kekuatan supranatural yang terdapat dalam cerita yaitu ulat yang muncul dari dalam kedua liang kubur mereka, Bunga Mendowe dan 
Janggu Rara. Meski kuburan keduanya saling berjauhan, ulat-ulat itu saling mengunjungi. Hal tersebut merupakan pertanda adanya kekuatan supranatural yang melatar belakangi kejadian itu.

\section{Motif}

Motif yang dapat ditemui dalam legenda Bunga Mendowe, yaitu motif perbuatan. Hal ini terbukti melalui penggambaran cerita yang dilakonkan karena meninggalkan kampung halamannya tanpa sepengetahuan kedua orang tuanya. Ayahnya pun jatuh sakit karena teringat terus anaknya yang hilang entah kemana, akibatnya ia meninggal dunia karenanya. Demikian pula tentang pernikahan yang tidak saling mencintai, membuat BM berselingkuh lalu dibunuh dengan cara yang amat sadis oleh suami Bunga Mendowe, yaitu dibakar dengan cara hidup-hidup. Keduanya pun akhirnya mati. Namun, ajaibnya. dengan kuasa Tuhan Yang Maha Esa, keduanya bisa hidup kembali dan menjadi seorang gadis yang cantik jelita. Demikian pula sang Pemuda menjadi lebih tampan dari sebelumnya. Setelah beberapa tahun mereka hidup rukun dan damai. BM pun meninggal dunia karena merasa berdosa menganggap kematian ayahnya disebabkan olehnya. Sang suami juga meninggal kemudian karena rasa cinta dan sayangnya kepada istrinya itu. Kini keduanya telah tiada. Namun, terjadi suatu keajaiban, meski keduanya telah mati, dan sudah dikubur dengan jarak yang cukup berjauhan, keduanya tetap saling mengunjungi dalam bentuk ulat.

\section{PENUTUP}

Cerita ini termaasuk jenis cerita legendayang diyakini kebenarannya oleh masyarakat pendukungnya. Penampilan tokoh BMsebagai tokoh sentral dan sebagian adegan yang diperankannya sulit diterima oleh akal, misalnya dibunuh dengan cara dibakar hingga menjadi abu kemudian bisa hidup kembali dan bahkan lebih cantik dan mudah daripada semula.

Legenda Bunga Mendowe ini merupakan simbol tersurat tentang proyeksi pikiran manusia akan cinta yang mengisahkan kisah cinta sejati antara BM dan JR yang tidak hanya terjalin di dunia. Namun, masih berlanjut setelah keduanya meninggal. Legenda ini memberikan pembelajaran pada kita tentang kehidupan rumah tangga yang seharusnya didasari dengan perasaan saling mencintai. Tanpa hal itu, biduk rumah tangga akan mudah goyah dan biasanya berakhir dengan perselingkuhan ataupun perpisahan. Seperti apa yang tergambar dalam cerita ini.

Cerita ini ditemukan di Desa Belajen, Kec. Duri. Ada pun latar cerita ini terjadi di salah satu daerah yang memiliki adat istiadat yang khas dan unik, yaitu di Uluwaidaerah Toraja, Baroko, bukit batu yang bernama paqbarani.

Dilihat dari sisi gagasan yang dominandari keseluruhan adagen dalam cerita (motif). Legenda ini berbicara tentang kawin terpaksa (menikah dengan seseorang karena ada rasa belas kasihan dan bukan karena cinta) dan terjadinya perselingkuhan. Dari cerita tentang perselngkuhan ini muncul suatu keyakinan bahwa menikah tanpa 
cinta sebaiknya dihindari karena efeknya amat jelek. Jelek bagi diri sendiri dan keluarga yang berselingkuh. Sementara itu, dilihat dari tipe cerita ini masuk dalam kategori tales of magic, yaitu cerita yang berhubungan dengan hal-hal yang supranatural. Hal ini dapat dibuktikan adanya kemampuan salah seorang tokoh dalam cerita yang mampu menghidupkan kembali BM dan JR yang sudah menjadi abu.

\section{DAFTAR PUSTAKA}

Ahimsa, Putra Heddy Shri. 2001. Strukturalisme Levi-Strauss. Legenda dan Karya Sastra. Yogyakarta: Galang, Press. . 2013. Strukturalisme LeviStrauss. Legenda dan Karya Sastra. Yogyakarta: Kepel Press.

Enre, Ambo Fachruddin, dkk. 1981. Sastra Lisan Bugis. Jakarta: Pusat Pembinaan dan Pengembangan Bahasa.

Damono, Sapardi Djoko. 1978. Sosiologi Sastra. Jakarta: Pusat Pembinaan dan Pengembangan Bahasa.

Eriyanto. 2013. Analisis Naratif: Dasar-dasar dan Penerapannya dalam Analisis Teks Berita Media. Jakarta: Kencana Prenada Media Group.

Pradopo, Rachmat Djoko. 2007. Beberapa Teori Sastra, Metode Kritik, dan Penerapannya. Yogyakarta: Pustaka Pelajar.

Sikki, Muhammad dkk. 1996. Struktur Sastra Lisan
Massenrempulu. Ujung

Pandang: Balai Penelitian Bahasa.

Taum, Yoseph Yapi. 2011. Studi Satrra Lisan: Sejarah, Teori, Metode, dan Pendekatan Disertai Contoh Penerapannya. Yogyakarta: Lamalera.

Todorov, Tzvetan. 1985. Tata Sastra. Terjemahan Okke K.S. Zaimar, Apsanti Djokosuyatno, dan Talha Bachmid. Jakarta: ILDEP dan Jambatan.k;

Zaidan, Abdul Rozak et.al. 2001. PedomanPenyuluhanApresiasi Sastra. Editor: NafronHasjim. Jakarta: PusatBahasa. 